\title{
Poly(ester imide)s Possessing Low CTE and Low Water Absorption (II). Effect of Substituents
}

\author{
By Masatoshi Hasegawa, ${ }^{*}$ Yumi TsujImURa, Kazunori KoSEKI, and Tatsuya MiYAZAKI
}

The film properties of a variety of poly(ester imide)s (PEsIs) were evaluated for development of a novel high temperature base film in flexible printed circuit (FPC) boards. In this work, three types of PEsI systems were systematically prepared from the following combinations of monomers: (1) ester-containing tetracarboxylic dianhydrides: hydroquinone bis(trimellitate anhydride) (TAHQ), methyl-substituted TAHQ (M-TAHQ), and methoxy-substituted TAHQ (MeO-TAHQ) with common diamines such as p-phenylenediamine (PDA), (2) common tetracarboxylic dianhydrides such as pyromellitic dianhydride (PMDA) with ester-containing diamines: 4-aminophenyl-4'-aminophenylbenzoate (APAB) and methyl-substituted APAB (ATAB), and (3) the TAHQ series with the APAB series. The effects of the substituents on the PEsI film properties and polymerizability were also discussed in this work. The ester-containing monomers used in this work (TAHQ series and the APAB series) were all highly reactive and led to PEsAAs possessing high inherent viscosities ranging 1.09-9.33 dL/g. The incorporation of methyl and methoxy substituents into rigid TAHQ-based PEsI systems caused no significant decrease in $T_{\mathrm{g}}$ but allowed molecular motions above the $T_{\mathrm{g}} \mathrm{s}$. In some cases, these substituents, in particular, the methoxy group contributed to a significant decrease in water absorption without sacrificing other target properties. For practical FPC application, a flexible diamine was copolymerized into the highly esterified rigid PEsI systems derived from the TAHQ series with the APAB series. One of the PEsI copolymers obtained achieved excellent combined properties: a low CTE (17.8 ppm/K) completely consistent with that of copper foil as a conductive layer, considerably low water absorption $(0.47 \mathrm{wt} \%)$, a high $T_{\mathrm{g}}$ exceeding $360{ }^{\circ} \mathrm{C}$, and improved toughness (elongation at break $>40 \%$ ).

KEY WORDS: Polyimides / Poly(ester imide)s / Linear Coefficient of Thermal Expansion (CTE) / Linear Coefficient of Humidity

Expansion (CHE) / Water Absorption / In-plane Orientation / Flexible Printed Circuit Boards (FPC) /

Polyimides (PIs) have been widely utilized in a variety of micro- and optoelectronic applications such as flexible printed circuit boards (FPC), chip on film (COF) assembling system, tape automated bonding tapes (TAB), buffer-coating films and interlayer dielectrics for LSI chips, high temperature adhesives, light wave guides for their combined excellent properties, i.e., high glass transition temperatures $\left(T_{\mathrm{g}}\right)$, high resistance to chemicals and radiation, relatively low dielectric constants, and good mechanical properties. ${ }^{1-10}$ The advantages of PI materials are considerably high purity (extremely low contents of metal contaminations and residual monomers and solvents) in the resins, simple fabrication processes, and the ease of structural modifications through copolymerization using various commercially available monomers.

FPC, TAB, and COF are fabricated from PI film/Cu foil laminates (flexible copper clad laminates, FCCL or CCL). Adhesive-free FCCL has an advantage in the view point of dimensional stability against heat cycles compared to that using thermally less stable conventional adhesives. This type of FCCL is usually produced by the casting method (thermal imidization after solution-casting of PI precursors, poly(amic acid)s (PAAs) onto a cupper foil) or the metalizing technique (Cu-plating after the formation of a $\mathrm{Ni}-\mathrm{Cr}$ sputtered seed layer). Particularly in the adhesive-free FCCL fabrication processes based on the casting method, the linear coefficients of thermal expansion (CTE) of PI layers must be precisely controlled to avoid some serious troubles arising from the CTE mismatching.

However, in many cases, PI films have much higher CTE values in the film plane direction ranging $40-80 \mathrm{ppm} \mathrm{K}^{-1}$ than those of conductive layers $\left(e . g ., 17 \mathrm{ppm} \mathrm{K}^{-1}\right.$ for cupper foil). This means that, when PI films (called base film) were formed on a metal substrate via thermal imidization after solution-casting of PAAs, the PI/metal laminates undergo thermal stress arising from the CTE mismatching during the cooling process from cure temperature to room temperature. Consequently it causes serious problems such as curling, cracking and detaching of the PI films. Therefore, considerable efforts for developing low-CTE PIs have been made. Systematic investigations on the structure-CTE relationship in various aromatic PI systems revealed that low-CTE PIs (as a temporal target, CTE $\leq 20 \mathrm{ppm} \mathrm{K}^{-1}$ ) have unexceptionally linear/stiff PI chain backbones. ${ }^{11,12}$ A typical lowCTE PI film is known as s-BPDA/PDA polyimide derived from 3,3',4,4'-biphenyltetracarboxylic dianhydride (s-BPDA) and p-phenylenediamine (PDA) and it is actually applied as a base film in TAB systems. This PI film exhibits CTE values ranging $5-20 \mathrm{ppm} \mathrm{K}^{-1}$ depending on a variety of factors such as the film thickness and the processing conditions. ${ }^{13,14}$ 
Low CTE characteristics observed in some limited PI systems are closely related to a thermal imidization-induced in-plane chain orientation phenomenon. We have previously proposed a hypothesis for its mechanism where stiff/ linear PI chain structures play a great role for a liquid crystallike interaction as a trigger for the self-orientation phenomenon. $^{13}$

However, "rod-like" tetracarboxylic dianhydride monomers reported previously, which lead to stiff linear PI backbones effective for the imidization-induced in-plane orientation, are limited to pyromellitic dianhydride (PMDA), s-BPDA, pterphenyltetracarboxylic dianhydride (TPDA), ${ }^{15-17}$ and 2,3,6,7naphthalenetetracarboxylic dianhydride $(2,3,6,7-\mathrm{NTDA})^{18}$ whereas much more kinds of diamines with stiff/linear structures are known and commercially available. We have previously demonstrated that a new type of tetracarboxylic dianhydride and diamine possessing para-ester linkages, i.e., hydroquinone bis(trimellitate anhydride) (TAHQ) and (4aminophenyl)-4'-aminobenzoate (APAB) are also classified into the concept of rod-like monomers. ${ }^{19}$

Another important subject to be solved for obtaining a next generation of high temperature dielectric materials in FCCL is the dimensional stability against absorbed water, which can be evaluated from the linear coefficient of humidity expansion (CHE). A primary key strategy for reducing CHE is to suppress water absorption in the resins as much as possible. Conventional polyimides such as PMDA/4, $4^{\prime}$-ODA system (PMDA = pyromellitic dianhydride, $4,4^{\prime}$-ODA $=4,4^{\prime}$-oxydianiline) tend to absorb water in air with a high extent compared to polyesters such as poly(ethylene terephthalate) (PET). This originates from a high content of highly polarized imide groups in the PI structures. We previously proposed a hybrid material between PIs and polyesters, namely, poly(ester imide)s (PEsIs) as a new material for FCCL and our results revealed that some PEsIs derived from TAHQ with APAB and a minor fraction of a flexible diamine as a comonomers achieved a very low extent of water absorption, a low CTE value approximate to copper foil, and excellent flexibility (film toughness) at the same time. ${ }^{19}$

Poly(ester imide)s have been so far studied only in the limited view points of film basic properties such as thermal stability and solubility, and mechanical properties, ${ }^{20-26}$ mechanical properties of fibers, ${ }^{27}$ liquid crystallinity ${ }^{28-30}$ without any attentions toward FCCL applications. Many of the previously reported poly(ester imide)s were synthesized via the direct polymerization of polyester from imide-containing diols with dicarboxylic acids without the pathway of thermal imidization which plays a great role for spontaneous in-plane orientation. In contrast, a prominent feature of our PEsI systems is that the PEsI films can be directly formed on cupper substrates via the conventional two step processes, thermal imidization after solution-casting of highly soluble their precursors.

In the present work, we also discuss the effects of substituents in ester-containing monomers on polymerizability and film properties.
Tetracarboxylic dianhydrides

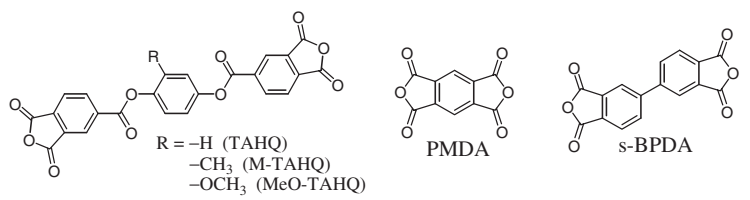

Diamines

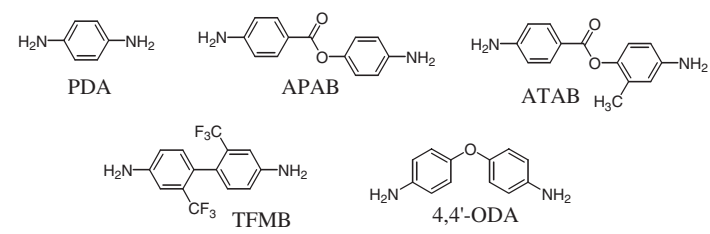

Figure 1. Molecular structures and abbreviations of monomers used.

Table I. Sources and conditions of pre-treatment and purification for monomers used

\begin{tabular}{|c|c|c|c|c|}
\hline Monomer & Source & $\begin{array}{c}\text { Solvent for } \\
\text { Recrystallization }\end{array}$ & $\begin{array}{l}\text { Vacuum-Drying } \\
\text { Condition }\end{array}$ & $\begin{array}{l}\text { Melting } \\
\text { point }{ }^{a)} \\
\left({ }^{\circ} \mathrm{C}\right)\end{array}$ \\
\hline PMDA & $\begin{array}{l}\text { Tokyo Chemical } \\
\text { Industry (TCI) }\end{array}$ & - & $150^{\circ} \mathrm{C} / 24 \mathrm{~h}$ & 287 \\
\hline s-BPDA & $\mathrm{TCl}$ & - & $200^{\circ} \mathrm{C} / 24 \mathrm{~h}$ & 300 \\
\hline TAHQ & - & 1,4-Dioxane & $200^{\circ} \mathrm{C} / 24 \mathrm{~h}$ & 277 \\
\hline M-TAHQ & - & $\begin{array}{l}\text { 1,4-Dioxane/ } \\
\text { THF }(4 / 1, v / v)\end{array}$ & $160^{\circ} \mathrm{C} / 24 \mathrm{~h}$ & 251 \\
\hline MeO-TAHQ & - & 1,4-Dioxane & $150^{\circ} \mathrm{C} / 24 \mathrm{~h}$ & 240 \\
\hline $\mathrm{PDA}^{\mathrm{b})}$ & $\mathrm{TCl}$ & Ethyl acetate & $50^{\circ} \mathrm{C} / 24 \mathrm{~h}$ & 142 \\
\hline APAB & Wakayama Seika & - & $50^{\circ} \mathrm{C} / 24 \mathrm{~h}$ & 185 \\
\hline ATAB & Wakayama Seika & - & $50^{\circ} \mathrm{C} / 24 \mathrm{~h}$ & 162 \\
\hline TFMB & Wakayama Seika & - & $50^{\circ} \mathrm{C} / 24 \mathrm{~h}$ & 184 \\
\hline $4,4^{\prime}-\mathrm{ODA}^{\mathrm{b})}$ & Wako Chemical & $\begin{array}{c}\text { Toluene/DMF } \\
(10 / 1, v / v)\end{array}$ & $50^{\circ} \mathrm{C} / 24 \mathrm{~h}$ & 187 \\
\hline
\end{tabular}

a) determined from the endothermic peak temperatures in the DSC thermograms recorded at a heating rate of $5^{\circ} \mathrm{C} \mathrm{min}-1$. b) purified by sublimation after recrystallization.

\section{EXPERIMENTAL}

\section{Materials}

The molecular structures, abbreviations, commercial sources, and melting points of the monomers used in this work are shown in Figure 1 and Table I. We used specially moleculardesigned ester-containing diamines, 4-aminophenyl-4'-aminobezoate (APAB) and 4-amino-3-methylphenyl-4'-aminobezoate (ATAB), supplied by Wakayama Seika Kogyo Corp., Ltd. All the solvents used were dried with molecular sieves $4 \mathrm{~A}$ prior to use.

We synthesized an ester-containing tetracarboxylic dianhydride monomer (methyl-substituted TAHQ: M-TAHQ) from trimellitic anhydride chloride (TMAC) and methylhydroquinone (MHQ) as reported in our previous work: ${ }^{19}$ MHQ $(40 \mathrm{mmol})$ was dissolved in a mixed solvent of $32 \mathrm{~mL}$ 
anhydrous tetrahydrofuran (THF) and $9.6 \mathrm{~mL}$ pyridine $(120$ mmol) as an acid acceptor in a double cap-sealed flask. In another sealed flask, TMAC $(80 \mathrm{mmol})$ was dissolved in anhydrous THF (107 mL). The MHQ solution was gradually added to the TMAC solution using a syringe at $0{ }^{\circ} \mathrm{C}$ with continuous magnetic stirring over $1 \mathrm{~h}$, then subsequently reacted at room temperature for $12 \mathrm{~h}$. The reaction mixture was filtrated out to collect the white precipitate consisting of crude product and pyridine/hydrochloride salt as a by-product. The precipitate was repeatedly washed with water to remove the salt until the absence of chlorine ion in the washing was confirmed from no formation of $\mathrm{AgCl}$ precipitate on a visual observation using a silver nitrate aqueous solution. Since the product undergoes partial hydrolysis toward anhydride ring opening on this procedure, it was heated at $160^{\circ} \mathrm{C}$ for $24 \mathrm{~h}$ in vacuum to ensure ring closure dehydration. The crude product obtained (yield: 66\%) was finally recrystallized from a mixed solvent of 1,4-dioxane/THF $(4 / 1, \mathrm{v} / \mathrm{v})$, then vacuum-dried again at $160{ }^{\circ} \mathrm{C}$ for $24 \mathrm{~h}$. The molecular structure of the purified product was confirmed to be M-TAHQ from FT-IR and ${ }^{1} \mathrm{H}-$ NMR spectra: FT-IR (KBr), $3104 \mathrm{~cm}^{-1}\left(\mathrm{C}_{\text {arom }}-\mathrm{H}\right.$ stretching), $2924 \mathrm{~cm}^{-1}\left(\mathrm{CH}_{3}, \mathrm{C}_{\text {aliph }}-\mathrm{H}\right.$ stretching $), 1863$ and $1784 \mathrm{~cm}^{-1}$ (acid anhydride $\mathrm{C}=\mathrm{O}$ stretching), $1738 \mathrm{~cm}^{-1}$ (aromatic ester $\mathrm{C}=\mathrm{O}$ stretching), $1493 \mathrm{~cm}^{-1}$ (phenylene group stretching). ${ }^{1} \mathrm{H}-$ NMR (dimethylsulfoxide- $\mathrm{d}_{6}$ ), $\delta 8.66\left[\mathrm{H}_{\mathrm{a}}+\mathrm{H}_{\mathrm{b}}, 4 \mathrm{H}\right.$ (relative integrated intensity: $3.95 \mathrm{H})], \delta 8.30\left[\mathrm{H}_{\mathrm{c}}, 2 \mathrm{H}(2.02 \mathrm{H})\right], \delta 7.46-$ $7.37\left[\mathrm{H}_{\mathrm{d}}+\mathrm{H}_{\mathrm{e}}+\mathrm{H}_{\mathrm{f}}, 3 \mathrm{H}(2.99 \mathrm{H})\right], \delta 2.25\left[\mathrm{R}=\mathrm{CH}_{3}, 3 \mathrm{H}\right.$ $(3.00 \mathrm{H})]$.

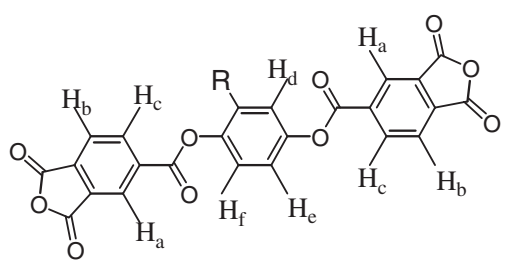

The final product also showed a sharp endothermic peak at the melting point $\left(250.5^{\circ} \mathrm{C}\right)$ in the differential scanning calorimetry (DSC) thermogram, suggesting a very high purity of the monomer. Methoxy-substituted TAHQ (MeO-TAHQ) was also synthesized in a similar manner from TMAC with methoxylhydroquinone, and its molecular structure and high purity was confirmed by FT-IR and ${ }^{1} \mathrm{H}-\mathrm{NMR}$ spectroscopy: FT-IR (KBr), $3102 \mathrm{~cm}^{-1}\left(\mathrm{C}_{\text {arom }}-\mathrm{H}\right.$ stretching $), 2938 \mathrm{~cm}^{-1}$ $\left(\mathrm{OCH}_{3}, \mathrm{C}_{\mathrm{aliph}}-\mathrm{H}\right.$ stretching), 1850 and $1782 \mathrm{~cm}^{-1}$ (acid anhydride $\mathrm{C}=\mathrm{O}$ stretching), $1738 \mathrm{~cm}^{-1}$ (aromatic ester $\mathrm{C}=\mathrm{O}$ stretching), $1507 \mathrm{~cm}^{-1}$ (phenylene group stretching). ${ }^{1} \mathrm{H}-\mathrm{NMR}$ (dimethylsulfoxide- $\mathrm{d}_{6}$ ), $\delta 8.64\left[\mathrm{H}_{\mathrm{a}}+\mathrm{H}_{\mathrm{b}}, 4 \mathrm{H}\right.$ (relative integrated intensity: $3.99 \mathrm{H})], \delta 8.31\left[\mathrm{H}_{\mathrm{c}}, 2 \mathrm{H}(2.05 \mathrm{H})\right], \delta 7.47-7.37$ $\left[\mathrm{H}_{\mathrm{e}}+\mathrm{H}_{\mathrm{f}}, 2 \mathrm{H}(2.00 \mathrm{H})\right], \delta 7.09\left[\mathrm{H}_{\mathrm{d}}, 1 \mathrm{H}(0.994 \mathrm{H})\right], \delta 3.80$ $\left[\mathrm{R}=\mathrm{OCH}_{3}, 3 \mathrm{H}(3.00 \mathrm{H})\right]$. The product also provided a sharp DSC peak at its melting point $\left(240.2^{\circ} \mathrm{C}\right)$.

PEsI precursors (PEsAAs) were prepared as follows unless stated otherwise: the equimolar amount of tetracarboxylic dianhydride powder was gradually added into the N,Ndimethylacetamine (DMAc) solution of diamines with stirring at room temperature for a prolonged period until the reaction mixture turned to a viscous/clear solution and the viscosities were stabilized. In this paper, the chemical compositions of PEsI systems are abbreviated using monomer components as $\mathrm{X} / \mathrm{Y}$ for homopolymers and $\mathrm{X} / \mathrm{Y}_{1} ; \mathrm{Y}_{2}$ for copolymers ( $\mathrm{X}=$ tetracarboxylic dianhydrides, $\mathrm{Y}=$ diamines).

The PEsAA solutions were doctor-bladed on a glass substrate to form various thick films and then dried at $60^{\circ} \mathrm{C}$ for $2 \mathrm{~h}$ in an air-convection oven. The PEsAA films obtained were thermally imidized as fixed on a glass substrate at established temperatures $\left(T_{\mathrm{i}}\right.$, typically $250^{\circ} \mathrm{C} / 1 \mathrm{~h}+300$ or $350{ }^{\circ} \mathrm{C} / 1 \mathrm{~h}$ ) in vacuum. The samples cured on a substrate were removed from the substrate and successively annealed at an established temperature $\left(T_{\mathrm{a}}\right.$, typically at $\mathrm{T}_{\mathrm{i}}+50^{\circ} \mathrm{C}$ for nonthermoplastic samples and at $T_{\mathrm{g}}-10^{\circ} \mathrm{C}$ for thermoplastic samples to avoid film deformation) for $1 \mathrm{~h}$ to remove the residual stress in the films. Imidization conditions were tuned to form a better quality of PEsI films when the standard cure condition caused some troubles such as brittle film formation and deformation. The detailed thermal conditions for film preparation are listed in Table II. The finally obtained PEsI films were all high-quality and completely clear. No cracks were observed in all PEsI films on a $180^{\circ}$ folding test, showing good flexibility. Complete thermal transformation from PEsAA to PEsI was confirmed from the disappearance of amide $\mathrm{C}=\mathrm{O}$ (1657, and $1556 \mathrm{~cm}^{-1}$ ) and hydrogen bonded $\mathrm{OH}$ (in $\mathrm{COOH}$, around $2600 \mathrm{~cm}^{-1}$ ) stretching bands and the appearance of the imide carbonyl specific bands [1781, 1725 (imide + ester), $1367,721 \mathrm{~cm}^{-1}$ ]. There were no practical changes in the FT-IR spectra between the imidized sample at $250{ }^{\circ} \mathrm{C}$ and the annealed samples at $300-400^{\circ} \mathrm{C}$, suggesting that PEsIs are thermally stable against any side reactions such as transesterification. ${ }^{19}$ No indication of thermal crosslinking in the DMTA curves, which is suggested from an increase in the storage modulus above the glass transition temperatures, was also observed for all PEsI films.

\section{Measurements}

The reduced viscosities $\left(\eta_{\text {red }}\right)$ of PEsAAs were measured at $0.5 \mathrm{wt} \%$ in DMAc at $30^{\circ} \mathrm{C}$ using an Ostwald viscometer. The values of $\eta_{\text {red }}$ obtained can be regarded as practically inherent viscosities $([\eta])$ since an extrapolation toward the zero concentration for determination of $[\eta]$ is disturbed an abnormal increase in the $\eta_{\text {red }}$ values at lower PAA concentrations by a polyelectrolyte effect. Then $[\eta]$ was used instead of $\eta_{\text {red }}$ from now on.

The CTE of the PI specimens $(20 \mathrm{~mm}$ long, $5 \mathrm{~mm}$ wide, and typically $20 \mu \mathrm{m}$ thick) was measured at a heating rate of $5^{\circ} \mathrm{C} \mathrm{min}^{-1}$ as an average within $100-200{ }^{\circ} \mathrm{C}$ for the film plane direction on a thermomechanical analyzer (Bruker-AXS, TMA 4010) with a load $(0.5 \mathrm{~g}$ per film thickness in $\mu \mathrm{m})$ in a nitrogen flow. In this case, the data were collected from the second heating run after the preliminary first run which was carried out up to $120^{\circ} \mathrm{C}$ to eliminate the adsorbed water. Storage modulus $\left(E^{\prime}\right)$ and loss energy $\left(E^{\prime \prime}\right)$ were measured as a function of temperature to determine glass transition temperature $\left(T_{\mathrm{g}}\right)$ from a peak temperature of the $E^{\prime \prime}$ curve using the same instrument 
Table II. Polymerization conditions and inherent viscosities of PEsAAs derived from ester-containing tetracarboxylic dianhydrides (TAHQ, M-TAHQ, and MeO-TAHQ) with common diamines and cure conditions

\begin{tabular}{|c|c|c|c|c|c|c|c|}
\hline Diamine & $\begin{array}{c}\text { Tetracarboxylic } \\
\text { Dianhydride }\end{array}$ & Solvent & $\begin{array}{l}\text { Solid content } \\
\text { (wt \%) }\end{array}$ & $\begin{array}{l}\text { Reaction } \\
\text { period } \\
\text { (h) }\end{array}$ & $\begin{array}{c}{[\eta]} \\
\left(\mathrm{dL} \mathrm{g}^{-1}\right)\end{array}$ & $\begin{array}{l}\text { Imidization } \\
\text { condition on } \\
\text { substrate }\end{array}$ & $\begin{array}{c}\text { Annealing } \\
\text { condition off } \\
\text { substrate }\end{array}$ \\
\hline \multirow{3}{*}{ PDA } & TAHQ & DMAC & $30 \rightarrow 9.0$ & 24 & 5.19 & $250^{\circ} \mathrm{C} / 2 \mathrm{~h}$ & $350^{\circ} \mathrm{C} / 1 \mathrm{~h}$ \\
\hline & M-TAHQ & DMAC & $25.7 \rightarrow 6.7$ & 67 & 9.33 & $\begin{array}{r}250^{\circ} \mathrm{C} / 1 \mathrm{~h} \\
+300^{\circ} \mathrm{C} / 1 \mathrm{~h}\end{array}$ & $350^{\circ} \mathrm{C} / 1 \mathrm{~h}$ \\
\hline & MeO-TAHQ & DMAC & $30 \rightarrow 14.0$ & 24 & 3.07 & $\begin{array}{c}250^{\circ} \mathrm{C} / 1 \mathrm{~h} \\
+350^{\circ} \mathrm{C} / 1 \mathrm{~h} \\
+370^{\circ} \mathrm{C} / 0.5 \mathrm{~h}\end{array}$ & $380^{\circ} \mathrm{C} / 1 \mathrm{~h}$ \\
\hline \multirow{3}{*}{ TFMB } & TAHQ & DMAC & $30 \rightarrow 9.3$ & 24 & 2.93 & $250^{\circ} \mathrm{C} / 2 \mathrm{~h}$ & $350^{\circ} \mathrm{C} / 1 \mathrm{~h}$ \\
\hline & M-TAHQ & DMAc & $30 \rightarrow 9.4$ & 67 & 3.79 & $250^{\circ} \mathrm{C} / 2 \mathrm{~h}$ & $300^{\circ} \mathrm{C} / 1 \mathrm{~h}$ \\
\hline & MeO-TAHQ & DMAC & $30 \rightarrow 14.6$ & 24 & 3.87 & $\begin{array}{r}250^{\circ} \mathrm{C} / 1 \mathrm{~h} \\
+350^{\circ} \mathrm{C} / 1 \mathrm{~h}\end{array}$ & $200^{\circ} \mathrm{C} / 1 \mathrm{~h}$ \\
\hline \multirow{3}{*}{$4,4^{\prime}-\mathrm{ODA}$} & TAHQ & DMAc & $30 \rightarrow 13.9$ & 24 & 1.10 & $250^{\circ} \mathrm{C} / 2 \mathrm{~h}$ & $300^{\circ} \mathrm{C} / 1 \mathrm{~h}$ \\
\hline & M-TAHQ & DMAc & $20 \rightarrow 10.8$ & 67 & 3.76 & $250^{\circ} \mathrm{C} / 2 \mathrm{~h}$ & $300^{\circ} \mathrm{C} / 1 \mathrm{~h}$ \\
\hline & MeO-TAHQ & DMAC & $30 \rightarrow 7.9$ & 24 & 7.03 & $\begin{array}{r}250^{\circ} \mathrm{C} / 1 \mathrm{~h} \\
+350^{\circ} \mathrm{C} / 1 \mathrm{~h}\end{array}$ & $330^{\circ} \mathrm{C} / 1 \mathrm{~h}$ \\
\hline
\end{tabular}

(TMA 4010) at a heating rate of $5^{\circ} \mathrm{C} \mathrm{min}^{-1}$ with a sinusoidal load frequency of $0.1 \mathrm{~Hz}$ in a nitrogen atmosphere.

Thermal stability of PEsI films was evaluated from the 5\% weight loss temperatures in the thermogravimetric analysis (Bruker-AXS, TGA2000) performed at a heating rate of $10{ }^{\circ} \mathrm{C} \mathrm{min}^{-1}$ in a nitrogen or an air flow.

The in-plane $\left(\mathrm{n}_{\text {in }}\right)$ and out-of-plane $\left(\mathrm{n}_{\text {out }}\right)$ refractive indices of the PEsI films were measured at D-line $(589 \mathrm{~nm})$ of a $\mathrm{Na}$ lamp on an Abbe refractometer (Atago 4T) equipped with a polarizer using a contact liquid (sulfur-saturated methylene iodide $\left.\mathrm{n}_{\mathrm{D}}=1.78-1.80\right)$ and a test piece $\left(\mathrm{n}_{\mathrm{D}}=1.92\right)$. The average refractive index was calculated from the relation: $\mathrm{n}_{\mathrm{av}}=\left(2 \mathrm{n}_{\mathrm{in}}+\mathrm{n}_{\text {out }}\right) / 3$. Dielectric constants were estimated from an empirical relation: $\varepsilon_{\mathrm{cal}}=1.1 \mathrm{n}_{\mathrm{av}}{ }^{2}$.

Ultraviolet-visible transmission spectra of PEsI films $(20 \mu \mathrm{m}$ thick) were recorded to evaluate the film transparency on a Jasco UV-VIS V-530 spectrometer.

The extent of water absorption $\left(\mathrm{W}_{\mathrm{A}}\right)$ was determined from the relation: $\left(\mathrm{W}-\mathrm{W}_{0}\right) / \mathrm{W}_{0} \times 100(\%)$, where $\mathrm{W}_{0}$ is the weight of PEsI films after immediately vacuum-drying at $50{ }^{\circ} \mathrm{C}$ for $24 \mathrm{~h}, \mathrm{~W}$ denotes the weight of PEsI films which were immersed in water at $25^{\circ} \mathrm{C}$ for $24 \mathrm{~h}$ and wiped completely out with a tissue paper. The imide contents were calculated from the relation: FW (imide)/FW (unit) $\times 100$ (wt \%) where $\mathrm{FW}$ (imide) and FW (unit) denote the formula weights of the imide group $(\mathrm{O}=\mathrm{C}-\mathrm{N}-\mathrm{C}=\mathrm{O})$ and the repeating units.

Tensile modulus, tensile strength, and elongation at break $\left(E_{b}\right)$ of the PI specimens $(3 \mathrm{~mm}$ wide and $30 \mathrm{~mm}$ long, sample numbers $>10$ ) were measured using a mechanical testing machine (Toyo Boldwin, Tensilon UTM-II) at a cross head speed of $8 \mathrm{~mm} \mathrm{~min}^{-1}$.

\section{RESULTS AND DISCUSSION}

\section{Molecular Design}

A possible strategy for further improvement of our PEsI properties is the incorporation of small sizes of side groups, since this approach do not alter basic properties of polymers such as $T_{\mathrm{g}}$ in many cases. However, we have previously reported a significant effect of the number and positions of a common substituent: the incorporation of two methyl groups (per the repeating unit) onto the s-BPDA/PDA backbone by the use of 2,5-dimethyl-1,4-phenylenediamine (DMPDA) instead of PDA completely inhibited the imidization-induced in-plane orientation phenomenon in our preliminary result, whereas relevant para-linked rigid PIs, s-BPDA/o-tolidine and s-BPDA/m-tolidine systems caused a high extent of in-plane orientation upon thermal imidization as well as the nonsubstituted s-BPDA/PDA system. These results gave us an empirical criterion on the molecular design for obtaining lowCTE PIs; one should avoid the incorporation of more than two substituents per an aromatic ring otherwise low CTE characteristics may be not obtained. Accordingly, mono-substituted monomers (M-TAHQ, MeO-TAHQ, and ATAB) were highlighted in this work.

\section{Homo PEsI Systems Derived from Ester-containing Tetra- carboxylic Dianhydrides with Common Diamines}

Polymerization. First of all, polymerization reactivity of the TAHQ series (TAHQ, M-TAHQ, and MeO-TAHQ) with common diamines was examined in this work. PDA was chosen as a typical diamine possessing a stiff/linear structure with an expectation that the resultant PEsI films would show low CTE characteristics as one of the most important targets.

In this case, polymerization reactivity can be evaluated from two parameters: the second order rate constants for polyaddition and the molecular weights (or simply intrinsic viscosities) of the finally obtained polymers. However, in the actual polyaddition processes, it is difficult to determine the rate constant since the reaction mixtures are usually inhomogeneous: the amic acid formation proceeds with dissolution of solid tetracarboxylic dianhydride monomers fed into diamine 
Table III. Film properties of PEsI systems derived from ester-containing tetracarboxylic dianhydrides (TAHQ, M-TAHQ, and MeO-TAHQ) with common diamines

\begin{tabular}{|c|c|c|c|c|c|c|c|c|c|c|c|}
\hline Diamine & $\begin{array}{c}\text { Tetracarboxylic } \\
\text { Dianhydride }\end{array}$ & $\begin{array}{c}T_{\mathrm{g}} \\
\left({ }^{\circ} \mathrm{C}\right)\end{array}$ & $\begin{array}{c}\text { CTE } \\
(\mathrm{ppm} / \mathrm{K})\end{array}$ & $\Delta \mathrm{n}$ & $\varepsilon_{\mathrm{cal}}$ & $\begin{array}{l}W_{A} \\
(\%)\end{array}$ & $\begin{array}{c}\text { Modulus } \\
\text { (GPa) }\end{array}$ & $\begin{array}{c}E_{b} \\
(\%)\end{array}$ & $\begin{array}{c}\text { Strength } \\
\text { (GPa) }\end{array}$ & $\begin{array}{c}T_{\mathrm{d}}^{5} \text { in } \\
\mathrm{N}_{2} \\
\left({ }^{\circ} \mathrm{C}\right)\end{array}$ & $\begin{array}{c}T_{\mathrm{d}}^{5} \text { in } \\
\text { air } \\
\left({ }^{\circ} \mathrm{C}\right)\end{array}$ \\
\hline \multirow{3}{*}{ PDA } & $\mathrm{TAHQ}$ & $N D^{a)}$ & 3.2 & 0.219 & 3.22 & 1.60 & 8.86 & 5.4 & 0.224 & 481 & 463 \\
\hline & M-TAHQ & $N D^{a)}$ & 2.7 & 0.207 & 3.22 & 1.00 & 8.14 & 2.5 & 0.116 & 476 & 456 \\
\hline & MeO-TAHQ & 397 & 4.5 & 0.147 & 3.17 & 1.21 & 6.49 & 3.3 & 0.130 & 452 & 433 \\
\hline \multirow{3}{*}{ TFMB } & TAHQ & $230^{\mathrm{b})} / 370^{\mathrm{c})}$ & 23.2 & 0.135 & 2.99 & 0.70 & 5.78 & 27.6 & 0.204 & 487 & 479 \\
\hline & M-TAHQ & $220^{\mathrm{b})} / 312^{\mathrm{d})}$ & 20.3 & 0.143 & 2.97 & 0.21 & 5.69 & 39.0 & 0.241 & 467 & 443 \\
\hline & MeO-TAHQ & $211^{\mathrm{b})}$ & 34.0 & 0.115 & 2.95 & 0.07 & 5.89 & 5.5 & 0.110 & 454 & 422 \\
\hline \multirow{3}{*}{$4,4^{\prime}-\mathrm{ODA}$} & $\mathrm{TAHQ}$ & 340 & 51.2 & 0.101 & 3.16 & 0.60 & 2.94 & 37.2 & 0.236 & 462 & 434 \\
\hline & M-TAHQ & 370 & 45.0 & 0.097 & 3.12 & 1.10 & 2.82 & 75.4 & 0.126 & 457 & 449 \\
\hline & MeO-TAHQ & 360 & 47.1 & 0.138 & 3.11 & 0.37 & 4.17 & 22.8 & 0.140 & 456 & 436 \\
\hline
\end{tabular}

a) ND $=$ not detected up to $450^{\circ} \mathrm{C}$ in dynamic mechanical thermal analysis (DMTA). b) $\beta$-transition (sub- $T_{\mathrm{g}}$ ). c) $\alpha$-transition ( $T_{\mathrm{g}}$ ) determined from DMTA and TMA curves. d) $\alpha$-transition ( $\left.T_{\mathrm{g}}\right)$ determined from TMA curves.

solutions. In addition, precipitation of the polymers formed also sometimes occurs in case of rigid structure systems. Therefore, in this paper, instead of 'polymerization reactivity,' we use a more qualitative term 'polymerizability' as a criterion representing how the polymerization of PEsAAs proceeds smoothly, as a result, afford higher molecular weight (higher $[\eta])$ PEsAAs. Thus, polymerizability is influenced by total effects of not only intrinsic monomer reactivity but also the solubility of the monomers and the polymers (oligomers or intermediates) formed. In other word, the use of monomers possessing higher intrinsic reactivity does not always give higher molecular weight polymers as illustrated from the fact that the use of much more reactive aliphatic diamines than aromatic ones causes the formation of insoluble salt. ${ }^{17,31}$

Table II lists the polymerization conditions and the inherent viscosities. In these systems using a fixed diamine (PDA), polymerization proceeded very smoothly with an abrupt increase in solution viscosities and led to considerably high inherent viscosities (3.07-9.33 dL/g) suggesting the formation of considerably high molecular weight PEsAAs in accordance with an empirical criterion that polyimide precursors possessing $[\eta]>1 \mathrm{dL} \mathrm{g}^{-1}$ always have good film flexibility. Film toughness is also a very important factor for FCCL applications.

Another 'rigid' diamine, TFMB was also used. This monomer has a lower reactivity than common aromatic diamines such as PDA owing to the presence of electronwithdrawing trifluoromethyl groups which bring about a decrease in the basicity. However, even TFMB provided high $[\eta]$ values ranging $2.93-3.87 \mathrm{dL} \mathrm{g}^{-1}$, reflecting that the present substituted TAHQs (M-TAHQ and MeO-TAHQ), as well as the non-substituted counterpart, were also highly reactive. No clear trend was observed for the order of substituent-dependent reactivity. A qualitative observation that the solution viscosity seemed to be more rapidly increased in the initial polymerization stage for the substituted TAHQ systems than for nonsubstituted TAHQ may be related to higher solubility of the substituted TAHQ monomers themselves in the solvent used in polymerization (in this case, DMAc).

PEsI Film Properties. Film properties of PEsI systems derived
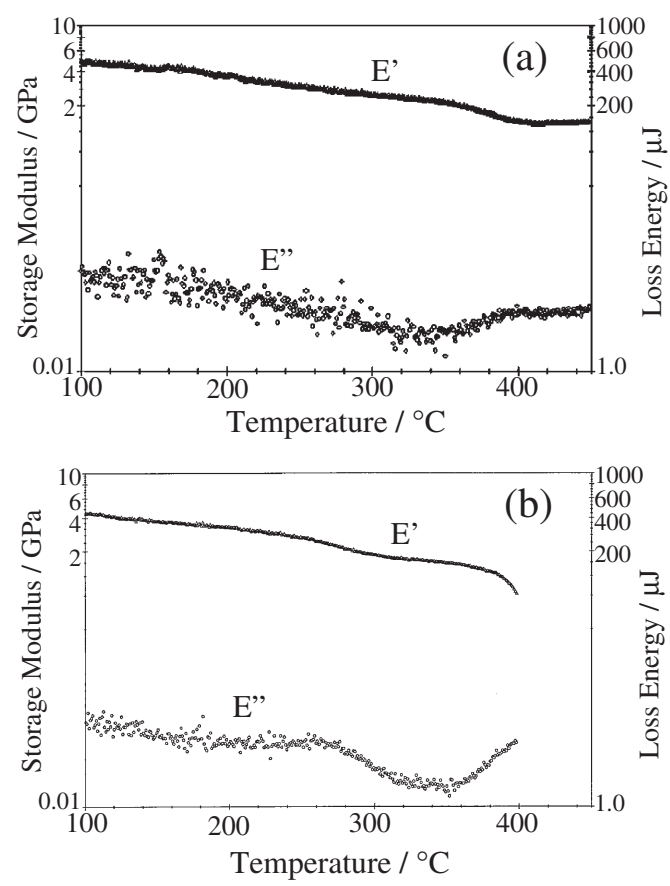

Figure 2. DMTA curves of PEsl films: (a) TAHQ/PDA and (b) MeO-TAHQ/ PDA systems.

from the TAHQ series with 'rigid' diamines are summarized in Table III. Our previous paper ${ }^{19}$ reported that the PEsI film of TAHQ/PDA system exhibited no distinct glass transitions in the DMTA curves (Figure 2a) as often observed in rod-like backbone structures of PI systems (for example, PMDA/PDA ${ }^{32}$ and s-BPDA/PDA systems ${ }^{33,34}$ ). This is attributed to significantly restricted molecular motion (internal rotation) and a semi-crystalline morphology (a decreased amorphous fraction). The M-TAHQ/PDA system also showed very similar DMTA curves with no appreciable distinct glass transitions (not shown). On the other hand, the incorporation of the methoxy group onto TAHQ allowed us to observe barely a glass transition at $397^{\circ} \mathrm{C}$ in DMTA curve although it was still far from being thermoplastic as shown in Figure 2b. As a result, the methoxy substitution was more effective to weaken 
intermolecular interaction than the methyl group, probably owing to higher bulkiness and higher local mobility.

It should be noted that the incorporation of these small substituents did not affect practically super low CTE characteristics $(\mathrm{CTE}=3.2 \mathrm{ppm} / \mathrm{K}$ for $\mathrm{TAHQ} / \mathrm{PDA}, 2.7 \mathrm{ppm} / \mathrm{K}$ for M-TAHQ/PDA, and $4.5 \mathrm{ppm} / \mathrm{K}$ for $\mathrm{MeO}-\mathrm{TAHQ} / \mathrm{PDA}$ ) in accordance with our molecular design criterion mentioned above. The results correspond to considerably high birefringence $\left(\Delta \mathrm{n}=\mathrm{n}_{\text {in }}-\mathrm{n}_{\text {out }}\right)$ values ranging $0.147-0.219$ which reflect qualitatively the high extents of in-plane orientation (polymer chain alignment into the direction parallel to the film plane, that is, anisotropic in the edge view but isotropic in the thru view). Common aromatic polymer films (e.g., poly(ether sulfone), polycarbonate etc.) prepared by the solution- or meltcasting process usually have much lower $\Delta \mathrm{n}$ values $(<0.005)$ corresponding to almost three-dimensionally random chain orientation. Thus, one recognizes how the polymer chains in the present PEsI samples are highly aligned parallel to the film plane.

A positive effect of the present substituents was observed on water absorption (1.6\% for TAHQ/PDA, $1.0 \%$ for M-TAHQ/ PDA, and $1.2 \%$ for MeO-TAHQ). In this case, the primary factors influencing water absorption are: (1) the content of highly polarized imide carbonyl groups in the structure and (2) crystallinity or the size and fraction of free volume in the amorphous region (molecular packing as more qualitative expression). A linear relationship was observed between the water absorption and the imide content (in wt \%) for various PEsI systems in our previous work, ${ }^{19}$ suggesting that to decrease the imide content by incorporating the aromatic ester linkages must be a key strategy for lowering water absorption. It is likely that the extent of molecular packing also influences water absorption, although no systematic research has been so far done. The present substitution effect on water absorption is predicted to be rather complex: the hydrophobic methyl and methoxy side groups on TAHQ not only positively contribute to a decrease in the imide content but also contribute to disturbing dense molecular packing.

Thermal stability was also estimated from the $5 \%$ weight loss temperatures. As listed in Table III, the thermal stability decreased in the following order: TAHQ/PDA > M-TAHQ/ PDA > MeO-TAHQ/PDA, probably reflecting the thermal stability of the substituents themselves. However, these systems are still sufficiently thermally stable even in an air atmosphere for the solder-reflowing processes in FPC fabrication (typically $270^{\circ} \mathrm{C} / 10 \mathrm{~s}$ ).

It should be noted that these PEsI films showed very high tensile strength $(0.116-0.224 \mathrm{GPa})$ and modulus (6.49-8.86 $\mathrm{GPa}$ ) with a parallel relationship to the birefringence. Film toughness is also one of the present targets for FPC application. In this work, film toughness was estimated from the elongation at break $\left(E_{b}\right)$ in the stretching test. Unfortunately, these homo PEsI systems did not show a high level of film toughness $\left(E_{b}>30 \%\right.$ as a temporal target) although these films were flexible (no cracks) from a $180^{\circ}$ folding test. Such insufficient film toughness is usually inevitable because of the poor chain entanglement arising from their rod-like backbone structures. However, as discussed later, the film toughness of rigid PEsI systems could be significantly improved by copolymerization using a minor fraction of a flexible ether-containing diamine without sacrificing other excellent properties.

In order to observe more clearly the effect of substituents on $T_{\mathrm{g}}$, a flexible diamine component, 4,4'-ODA was used instead of 'rigid' PDA, thereby glass transitions are expected to become detectable on DMTA measurements. The $T_{\mathrm{g}}$ and other film properties of the 4,4'-ODA-based homo PEsI systems are also listed in Table III. The non-substituted TAHQ/4,4'-ODA system showed a high $T_{\mathrm{g}}$ at $340^{\circ} \mathrm{C}$ with a broad transition around $210^{\circ} \mathrm{C}$ in the DMTA curve (this lower temperature transition will be discussed later). The results revealed that the effect of the methoxy and methyl substituents caused a certain degree of $T_{\mathrm{g}}$ increase $\left(20-30^{\circ} \mathrm{C}\right)$ as shown in Table III. This can be interpreted in terms of suppressed internal rotation of the central hydroquinone moiety by some steric hindrance due to the present small substituents. If another more bulky substituent (such as phenyl group) were incorporated instead of the present methyl and methoxy groups, a decrease in $T_{\mathrm{g}}$ would be caused as speculated from our previous data ${ }^{35}$ that $T_{\mathrm{g}}=236^{\circ} \mathrm{C}$ for non-substituted ODPA/TPEQ and $T_{\mathrm{g}}=212^{\circ} \mathrm{C}$ for phenyl-substituted ODPA/PTPEQ where ODPA $=$ oxydiphthalic anhydride, TPEQ $=1$,4-bis(4-aminophenoxy)benzene, PTPEQ = 1,4-bis(4-aminophenoxy)-2-phenylbenzene. The present TAHQ series $/ 4,4^{\prime}$-ODA systems also showed much higher CTE values ranging 47.1 to $51.2 \mathrm{ppm} / \mathrm{K}$ in addition to much lower tensile modulus than the rigid PEsI systems mentioned above, as predicted from their non-linear backbone structures but still lower than the values of common flexible PI systems (usually 60-80 ppm/K). The result corresponds to the comparatively high degree of in-plane orientation as suggested from their relatively high birefringence $(\Delta \mathrm{n}=$ 0097-0.138). A pronounced feature of the present $4,4^{\prime}$ ODA-based PEsI films is good toughness. Particularly, the M-TAHQ/4,4'-ODA film possessed a very high $E_{b}$ value exceeding $75 \%$. Thus, in the present systems, the use of $4,4^{\prime}$ ODA was very effective for improvement of film toughness, suggesting that 4,4'-ODA can be an excellent comonomer for rigid PEsI systems as discussed later. However, note that the use of 4,4'-ODA does not always provide highly tough PI films; an isomeric PEsI system, derived from 4,4'-ODA with a TAHQ isomer synthesized from 4-hydroxyphthalic anhydride and terephthaloyl dichloride, showed insufficient film toughness $\left(\mathrm{E}_{\mathrm{b}}<10 \%\right)$ in contrast to our first expectation although its detailed mechanism is not clear yet. ${ }^{36}$

The film properties of the TAHQ series-based PEsIs using another rigid diamine, TFMB were also evaluated. In this case, a pronounced substitution effect on thermal transitions was observed in the DMTA curves. The non-substituted TAHQ/ TFMB system provided an abrupt decrease in $\mathrm{E}^{\prime}$ at $370^{\circ} \mathrm{C}$ (Figure 3a) with a broad transition around $230^{\circ} \mathrm{C}$. This 'double transition' behavior in the DMTA curves was also observed in to the TAHQ/4,4'-ODA system as shown in Figure 3b. The primary transition at $370^{\circ} \mathrm{C}$ for TAHQ/TFMB must be due to 

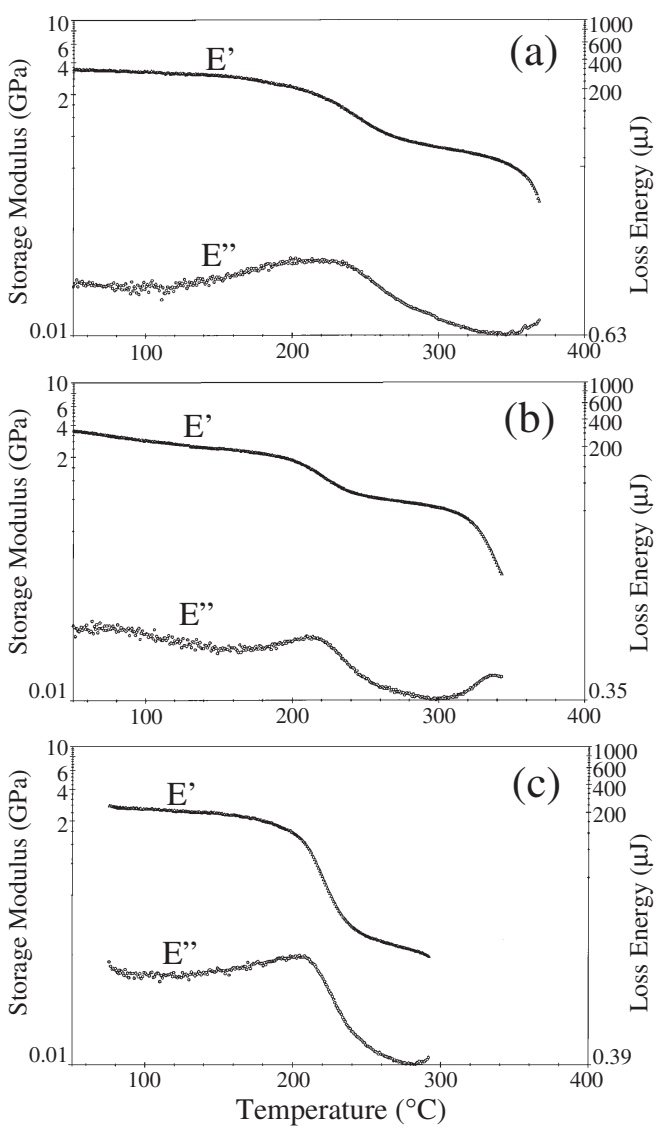

Figure 3. DMTA curves of PEsl films: (a) TAHQ/TFMB, (b) TAHQ/4,4'-ODA, and (c) M-TAHQ/TFMB systems.

the $\alpha$-transition $\left(T_{\mathrm{g}}\right)$ since it is in accordance with an abrupt film elongation (softening) in the thermomechanical analysis (TMA) conducted under a fixed load, whereas the second transition around $230{ }^{\circ} \mathrm{C}$ is temporally assumed to be the $\beta$ transition (sub- $T_{\mathrm{g}}$ ). On the other hand, in the substituted TAHQ-based systems (M-TAHQ/TFMB and MeO-TAHQ/ TFMB), it should be noted that these lower temperature transitions appeared around $220^{\circ} \mathrm{C}$ for M-TAHQ/TFMB and $211^{\circ} \mathrm{C}$ for MeO-TAHQ are significantly intensified as typically shown in the DMTA curves of the M-TAHQ/TFMB film in Figure $3 \mathrm{c}$. In this case, it is likely that the $\alpha$-transitions are seemingly hidden by an instrumental circumstance (an automatic stop system operating when total film elongation exceeded an upper limit). The intensified broad transition temperatures over $200-240^{\circ} \mathrm{C}$ seem to be too low as the glass transition temperatures, namely, the lower temperature transitions do not correspond to the $\alpha$-transition but the $\beta$ transition. This assumption can be supported by the fact that the present small substituents did not basically contribute to a significant decrease in $T_{\mathrm{g}}$ for the 4,4'-ODA-derived PEsI systems mentioned above (see Table III). The substituted MTAHQ/TFMB film exhibited an abrupt film elongation at $313^{\circ} \mathrm{C}$ in the TMA curve recorded under a fixed load as shown in Figure 4. This softening temperature can be regarded as the glass $(\alpha)$ transition, although for the MeO-TAHQ system the

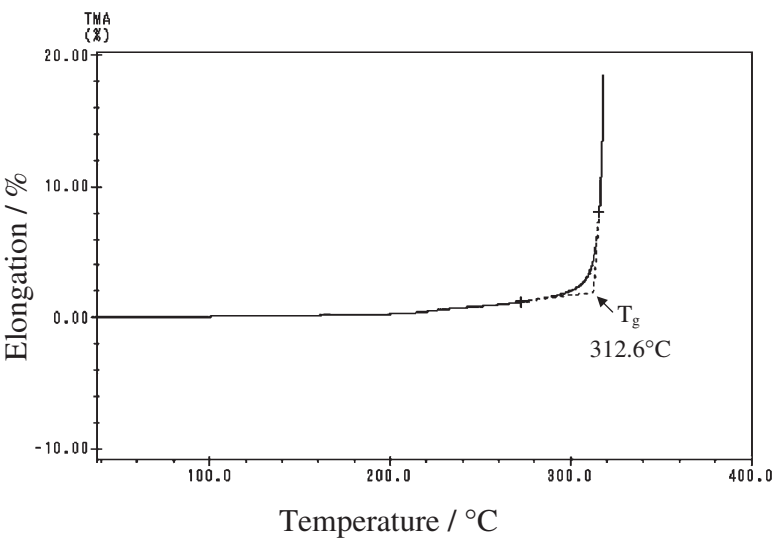

Figure 4. TMA curve of M-TAHQ/TFMB PEsI film.

determination of $T_{\mathrm{g}}$ from this TMA approach was unfortunately disturbed by the same instrumental reason mentioned above.

The intensified $\beta$ transitions seem to be intrinsic to the substituted TAHQ/TFMB systems. But recall that weaker $\beta$ transitions are also observed in the non-substituted TAHQ/ TFMB and TAHQ series/4,4'-ODA. In contrast, even if TFMB was used as a diamine component, considerably rigid PI systems such as PMDA/TFMB $\left(T_{\mathrm{g}}=400^{\circ} \mathrm{C}\right)^{18}$ usually show no appreciable $\beta$-transitions in the DMTA measurements. Therefore, it can be assumed that the observed $\beta$ transitions are related to local rotational motions around the ester linkages at the TAHQ moiety, which can be more strongly allowed when substituted TAHQ were combined with fluorinated diamines such as TFMB contributing to weaken intermolecular interactions.

These TFMB-based PEsI systems also showed relatively low CTE values ranging 20.3-34.0 ppm/K with no clear trend for the substitution effect. The optically estimated dielectric constant slightly decreased from 2.99 to 2.97 , and 2.95 on going from TAHQ/TFMB, M-TAHQ/TFMB, and MeOTAHQ/TFMB, in contrast, the extent of water absorption drastically decreased from 0.7 to 0.21 , and finally to $0.07 \%$. These TFMB-based PEsI films also possessed high modulus (5.69-5.89 GPa) and high strength in addition to sufficient film toughness $\left(\mathrm{E}_{\mathrm{b}}=39.0 \%\right.$ for M-TAHQ/TFMB) except for the MeO-TAHQ/TFMB system $\left(\mathrm{E}_{\mathrm{b}}=5.5 \%\right)$. A feature of these TFMB-based PEsI systems is to show comparatively high transparency in the ultraviolet-visible wavelength range, although "transmittance" is beyond the present target. PI film transparency is closely related to intra- and intermolecular charge-transfer (CT) interactions. ${ }^{37}$ In the fields of photosensitive PI systems, one concerns the film transparency of PI precursors, poly(amic acid)s (PAAs), rather than PI films themselves. Empirically speaking, the qualitative order of PI film transparency seems to be also kept in that of PAA film transparency. The present TFMB-based PEsAA films possessed much higher transparency than the corresponding common TFMB-based PAA systems. Therefore we have successfully applied the present TFMB-based PEsI systems 
Table IV. Polymerization conditions and inherent viscosities of PEsAAs derived from ester-containing diamines (APAB and ATAB) with common tetracarboxylic dianhydrides and cure conditions

\begin{tabular}{|c|c|c|c|c|c|c|c|}
\hline $\begin{array}{l}\text { Tetracarboxylic } \\
\text { Dianhydride }\end{array}$ & Diamine & Solvent & $\begin{array}{c}\text { Solid } \\
\text { content } \\
\text { (wt \%) }\end{array}$ & $\begin{array}{l}\text { Reaction } \\
\text { period (h) }\end{array}$ & $\begin{array}{c}{[\eta]} \\
\left(\mathrm{dL} \mathrm{g}^{-1}\right)\end{array}$ & $\begin{array}{l}\text { Imidization } \\
\text { condition on } \\
\text { substrate }\end{array}$ & $\begin{array}{l}\text { Annealing } \\
\text { condition } \\
\text { off substrate }\end{array}$ \\
\hline \multirow{3}{*}{ PMDA } & \multirow{2}{*}{ APAB } & DMAc & $30 \rightarrow 15.6$ & 123 & 0.41 & - & - \\
\hline & & NMP & 10 & 37 & 1.09 & $\begin{array}{r}250^{\circ} \mathrm{C} / 1 \mathrm{~h} \\
+300^{\circ} \mathrm{C} / 1 \mathrm{~h}\end{array}$ & $350^{\circ} \mathrm{C} / 1 \mathrm{~h}$ \\
\hline & ATAB & DMAC & $30 \rightarrow 12.0$ & 34 & 2.22 & $\begin{array}{r}250^{\circ} \mathrm{C} / 1 \mathrm{~h} \\
+300^{\circ} \mathrm{C} / 1 \mathrm{~h}\end{array}$ & $350^{\circ} \mathrm{C} / 1 \mathrm{~h}$ \\
\hline \multirow{2}{*}{ s-BPDA } & APAB & DMAC & $30 \rightarrow 13.6$ & 48 & 2.30 & $\begin{array}{r}250^{\circ} \mathrm{C} / 1 \mathrm{~h} \\
+300^{\circ} \mathrm{C} / 1 \mathrm{~h}\end{array}$ & $350^{\circ} \mathrm{C} / 1 \mathrm{~h}$ \\
\hline & ATAB & DMAC & $30 \rightarrow 13.8$ & 40 & 2.02 & $\begin{array}{r}250^{\circ} \mathrm{C} / 1 \mathrm{~h} \\
+300^{\circ} \mathrm{C} / 1 \mathrm{~h}\end{array}$ & $350^{\circ} \mathrm{C} / 1 \mathrm{~h}$ \\
\hline
\end{tabular}

to low-CTE and high-modulus transparent positive-type photosensitive polyimide systems for buffer-coating in IC chips. ${ }^{38}$

Our preliminary experiments showed that a PEsI model compound derived from TAHQ and 4-octylaniline possessed a freezing point at $283^{\circ} \mathrm{C}$ in the DSC cooling process and a stable liquid crystalline phase under a polarizing optical microscope in the range between the freezing point and a clearing point at $348^{\circ} \mathrm{C}$, whereas the counterpart prepared from M-TAHQ showed a lower freezing point at $238^{\circ} \mathrm{C}$ and no stable liquid crystalline phase in a narrow range between the freezing point and a clearing point at $270^{\circ} \mathrm{C}$ although only a trace of an anisotropic texture was observed at $250^{\circ} \mathrm{C}$ under a shear. The results suggest the presence of some intermolecular interaction between the TAHQ-based diimide units behaving as a mesogen, and the methyl substituent of M-TAHQ may partially disturb it owing to a steric effect. If there is a similar situation for the difference of intermolecular interactions in the actual TAHQ- and M-TAHQ-based PEsI systems, the allowed $\beta$ transition (probably local rotational motions around the ester linkages) in the substituted TAHQ/TFMB systems as mentioned above may arise from the prevented diimide-diimide intermolecular interaction by the substituents.

Homo PEsI Systems Derived from Ester-containing Diamines with Common Tetracarboxylic Dianhydrides

Polymerization. The study of the substituent effect was also extended to PEsI systems derived from the APAB series (APAB and ATAB) with common tetracarboxylic dianhydrides. The polymerization results are listed in Table IV. A qualitative observation suggested that $\mathrm{APAB}$ is highly reactive with PMDA in DMAc; the solution viscosity rapidly increased within $30 \mathrm{~min}$ after feeding of the monomers was completed. Then, a homogeneous reaction mixture was temporally obtained at the initial stage with an increased solution viscosity, however, it became turbid gradually and remained inhomogeneous even after prolonged stirring at room temperature probably owing to precipitation of the polymer (or oligomer) formed. This is attributed to poor solubility of the products in DMAc. In contrast, the use of NMP as another polymerization solvent allowed homogeneous polymerization without any precipitation and gelation and led to the formation of a higher molecular weight PEsAA $([\eta]=1.09 \mathrm{dL} / \mathrm{g}$ in NMP) than in DMAc $([\eta]=0.41 \mathrm{dL} / \mathrm{g})$. On the other hand, the methyl-substituted PMDA/ATAB system caused no precipitation even in DMAc. This can be interpreted in terms of a steric effect of the methyl substituent in ATAB on aggregation between the formed PEsAA chains during the polymerization. Consequently, the PMDA/ATAB system provided a much higher inherent viscosity $(2.22 \mathrm{dL} / \mathrm{g})$ even in DMAc.

It is likely that the position of the methyl substituent affects the polymerizability. In the present case, the methyl group of ATAB is incorporated at the meta-position of the amino group, as a result, ATAB showed good reactivity as well as common aromatic diamines such as 4,4'-ODA. If this substituent was incorporated at the ortho-position of the amino group, the resultant inherent viscosity would be much lower owing to its steric effect negatively working on the polymerization reactivity with tetracarboxylic dianhydrides. This is predicted from a similar situation that an ortho-methyl-substituted diamine, 4,4'-methylenebis(2-methylaniline) is empirically always less reactive with common tetracarboxylic dianhydrides than the corresponding non-substituted 4,4'-methylenedianiline.

On the other hand, in the s-BPDA systems, no appreciable effect of the methyl substituent was observed on the polymerizability as suggested from the comparable values of inherent viscosities between the APAB $([\eta]=2.30 \mathrm{dL} / \mathrm{g})$ and ATAB $(2.02 \mathrm{dL} / \mathrm{g})$ systems. This may be due to sufficiently high solubility of the s-BPDA-based PEsAAs during the polymerization even when non-substituted APAB was used.

PEsI Film Properties. Film properties of PEsI systems derived from the APAB series with common tetracarboxylic dianhydrides are summarized in Table V. In this case, PMDA and s-BPDA possessing rigid/linear structures were chosen as tetracarboxylic dianhydride components with a strong expectation of showing low CTE characteristics. The PMDA/APAB system exhibited excellent combined properties comparable to TAHQ/PDA system; undetectable glass transition (excellent dimensional stability against thermal cycles), a super-low CTE of $2.0 \mathrm{ppm} / \mathrm{K}$, a very high tensile modulus $(7.69 \mathrm{GPa})$ and strength $(0.270 \mathrm{GPa})$, and a relatively low water absorption (1.6\%). The PMDA/APAB film also showed higher 5\% weight loss temperatures $\left(T_{\mathrm{d}}{ }^{5}=531^{\circ} \mathrm{C}\right.$ in $\mathrm{N}_{2}$ and $501{ }^{\circ} \mathrm{C}$ in air $)$ than 
Table V. Film properties of PEsl systems derived from ester-containing diamines (APAB and ATAB) with common tetracarboxylic dianhydrides

\begin{tabular}{|c|c|c|c|c|c|c|c|c|c|c|c|}
\hline $\begin{array}{c}\text { Tetracarboxylic } \\
\text { Dianhydride }\end{array}$ & Diamine & $\begin{array}{c}T_{\mathrm{g}} \\
\left({ }^{\circ} \mathrm{C}\right)\end{array}$ & $\begin{array}{c}\text { CTE } \\
(\mathrm{ppm} / \mathrm{K})\end{array}$ & $\Delta \mathrm{n}$ & $\varepsilon_{\text {cal }}$ & $\begin{array}{l}W_{A} \\
(\%)\end{array}$ & $\begin{array}{l}\text { Modulus } \\
\text { (GPa) }\end{array}$ & $\begin{array}{l}E_{b} \\
(\%)\end{array}$ & $\begin{array}{c}\text { Strength } \\
\text { (GPa) }\end{array}$ & $\begin{array}{c}T_{\mathrm{d}}^{5} \text { in } \\
\mathrm{N}_{2} \\
\left({ }^{\circ} \mathrm{C}\right)\end{array}$ & $\begin{array}{c}T_{\mathrm{d}}{ }^{5} \\
\text { in air } \\
\left({ }^{\circ} \mathrm{C}\right)\end{array}$ \\
\hline \multirow[b]{2}{*}{ PMDA } & APAB & $N D^{a)}$ & 2.0 & 0.172 & 3.29 & 1.60 & 7.69 & 6.4 & 0.270 & 531 & 501 \\
\hline & ATAB & $N D^{a)}$ & 0.8 & 0.196 & 3.24 & 1.70 & 7.98 & 4.5 & 0.213 & 509 & 482 \\
\hline \multirow[b]{2}{*}{ s-BPDA } & APAB & $N D^{a)}$ & 3.4 & 0.183 & 3.28 & 0.70 & 7.59 & 6.0 & 0.250 & 534 & 525 \\
\hline & ATAB & $N D^{a)}$ & 6.5 & 0.177 & 3.27 & 0.70 & 9.38 & 5.0 & 0.270 & 515 & 491 \\
\hline
\end{tabular}

a) $\mathrm{ND}=$ not detected up to $450^{\circ} \mathrm{C}$ in dynamic mechanical thermal analysis (DMTA).

Table VI. Polymerization conditions and inherent viscosities of PEsAAs derived from ester-containing tetracarboxylic dianhydrides (TAHQ, M-TAHQ, and MeO-TAHQ) with ester-containing diamines (APAB and ATAB) and cure conditions

\begin{tabular}{|c|c|c|c|c|c|c|c|}
\hline Diamine & $\begin{array}{c}\text { Tetracarboxylic } \\
\text { Dianhydride }\end{array}$ & Solvent & $\begin{array}{l}\text { Solid content } \\
\text { (wt \%) }\end{array}$ & $\begin{array}{l}\text { Reaction } \\
\text { period } \\
\text { (h) }\end{array}$ & $\begin{array}{c}{[\eta]} \\
\left(\mathrm{dL} \mathrm{g}^{-1}\right)\end{array}$ & $\begin{array}{l}\text { Imidization } \\
\text { condition on } \\
\text { substrate }\end{array}$ & $\begin{array}{l}\text { Annealing } \\
\text { condition of } \\
\text { substrate }\end{array}$ \\
\hline \multirow{3}{*}{ APAB } & $\mathrm{TAHQ}$ & DMAC & $30 \rightarrow 11.2$ & 48 & 2.81 & $\begin{array}{r}250^{\circ} \mathrm{C} / 1 \mathrm{~h} \\
+300^{\circ} \mathrm{C} / 1 \mathrm{~h}\end{array}$ & $350^{\circ} \mathrm{C} / 1 \mathrm{~h}$ \\
\hline & M-TAHQ & DMAC & $20 \rightarrow 11.0$ & 67 & 4.03 & $250^{\circ} \mathrm{C} / 2 \mathrm{~h}$ & $350^{\circ} \mathrm{C} / 1 \mathrm{~h}$ \\
\hline & MeO-TAHQ & DMAC & $30 \rightarrow 14.3$ & 24 & 3.42 & $\begin{array}{r}250^{\circ} \mathrm{C} / 1 \mathrm{~h} \\
+350^{\circ} \mathrm{C} / 1 \mathrm{~h}\end{array}$ & $300^{\circ} \mathrm{C} / 2 \mathrm{~h}$ \\
\hline \multirow{3}{*}{ ATAB } & TAHQ & DMAC & $30 \rightarrow 13.0$ & 20 & 2.06 & $\begin{array}{r}250^{\circ} \mathrm{C} / 1 \mathrm{~h} \\
+300^{\circ} \mathrm{C} / 1 \mathrm{~h}\end{array}$ & $350^{\circ} \mathrm{C} / 1 \mathrm{~h}$ \\
\hline & M-TAHQ & DMAC & $20 \rightarrow 11.1$ & 67 & 3.17 & $\begin{array}{r}250^{\circ} \mathrm{C} / 1 \mathrm{~h} \\
+350^{\circ} \mathrm{C} / 1 \mathrm{~h}\end{array}$ & $300^{\circ} \mathrm{C} / 2 \mathrm{~h}$ \\
\hline & MeO-TAHQ & DMAC & $30 \rightarrow 15.0$ & 24 & 1.47 & $\begin{array}{r}250^{\circ} \mathrm{C} / 1 \mathrm{~h} \\
+350^{\circ} \mathrm{C} / 1 \mathrm{~h}\end{array}$ & $355^{\circ} \mathrm{C} / 2 \mathrm{~h}$ \\
\hline
\end{tabular}

the TAHQ/PDA film $\left(T_{\mathrm{d}}{ }^{5}=481^{\circ} \mathrm{C}\right.$ in $\mathrm{N}_{2}$ and $463^{\circ} \mathrm{C}$ in air $)$. The higher thermal stability of PMDA/APAB can be assumed to be due to a lower content of ester linkages than TAHQ/ PDA.

A comparison of film properties between PMDA/APAB and PMDA/ATAB revealed that the PMDA/ATAB film also exhibited similarly excellent properties with no significant substituent effect except for a further decreased CTE $(0.8 \mathrm{ppm} /$ K) and decreased $T_{\mathrm{d}}{ }^{5}$ for the PMDA/ATAB system. The decreased thermal stability is attributed to the presence of thermally less stable methyl substituent as well as in the comparison between non-substituted TAHQ/PDA and methylsubstituted M-TAHQ/PDA, although the thermal stability of the PMDA/ATAB film is still sufficiently high $\left(T_{\mathrm{d}}{ }^{5}=509^{\circ} \mathrm{C}\right.$ in $\mathrm{N}_{2}$ and $482^{\circ} \mathrm{C}$ in air, each value is still higher than that of non-substituted TAHQ/PDA).

The substituent effect was also examined using another tetracarboxylic dianhydride, s-BPDA. The s-BPDA/APAB system also similar excellent combined properties; undetectable $T_{\mathrm{g}}$, a super-low CTE of $3.4 \mathrm{ppm} / \mathrm{K}$, a very high tensile modulus $(7.59 \mathrm{GPa})$ and strength $(0.250 \mathrm{GPa})$. In this case, a positive effect was observed by using s-BPDA instead of PMDA, that is, a significantly decreased extent of water absorption $(0.7 \%)$ and a somewhat increased $T_{\mathrm{d}}{ }^{5}$. The decreased water absorption is most likely attributed to the decreased imide content, corresponding to a linear correlation between the water absorption and the imide content (in wt \%) as illustrated in various PEsI systems in our previous work. ${ }^{19}$ Our previous paper reported that 2,3,6,7-naphthalenetetracarboxylic dianhydride, as well as s-BPDA, is also effective in this regard. ${ }^{18}$ Thus, in comparison between the APAB- and ATABbased homo PEsI systems, almost no substituent effect positively working on the film properties were observed although some PEsI copolymer systems undergo significant improvement of film toughness by the substituent effect as discussed later.

\section{Homo PEsI Systems Derived from Ester-containing Dia- nhydrides with Ester-containing Diamines}

Highly esterified PEsIs were also prepared from the TAHQ series with the APAB series. In these systems, smooth polymerization was allowed without any problems such as precipitation and gelation and led to PEsAAs of sufficiently high inherent viscosities ranging $1.47-4.03 \mathrm{dL} / \mathrm{g}$ as listed in Table VI. These PEsAA solutions all remained completely homogeneous during storage even at $-20^{\circ} \mathrm{C}$. As shown in Table VI, some clear trends demonstrating a positive effect of the substituents on the inherent viscosity were not observed in the present systems in contrast to the PMDA/ATAB system mentioned above, probably owing to sufficiently high solubility during the polymerization even in the non-substituted TAHQ/ $\mathrm{APAB}$ system as in the above-mentioned comparison between s-BPDA/APAB and s-BPDA/ATAB.

Table VII summarizes the film properties of the PEsI systems derived from the TAHQ series with the APAB series. The data of the non-substituted TAHQ/APAB system were extracted from our previous paper ${ }^{19}$ and listed in this table for a comparison, that is, undetectable $T_{\mathrm{g}}$, a super-low CTE of 
Table VII. Film properties of PEsl systems derived from ester-containing tetracarboxylic dianhydrides (TAHQ, M-TAHQ, and MeO-TAHQ) with ester-containing diamines (APAB and ATAB)

\begin{tabular}{|c|c|c|c|c|c|c|c|c|c|c|c|}
\hline Diamine & $\begin{array}{c}\text { Tetracarboxylic } \\
\text { Dianhydride }\end{array}$ & $\begin{array}{c}T_{\mathrm{g}} \\
\left({ }^{\circ} \mathrm{C}\right)\end{array}$ & $\begin{array}{c}\text { CTE } \\
(\mathrm{ppm} / \mathrm{K})\end{array}$ & $\Delta \mathrm{n}$ & $\varepsilon_{\text {cal }}$ & $\begin{array}{l}W_{A} \\
(\%)\end{array}$ & $\begin{array}{l}\text { Modulus } \\
\text { (GPa) }\end{array}$ & $\begin{array}{l}E_{b} \\
(\%)\end{array}$ & $\begin{array}{l}\text { Strength } \\
\text { (GPa) }\end{array}$ & $\begin{array}{c}T_{\mathrm{d}}^{5} \text { in } \\
\mathrm{N}_{2} \\
\left({ }^{\circ} \mathrm{C}\right)\end{array}$ & $\begin{array}{c}T_{\mathrm{d}}^{5} \text { in } \\
\text { air } \\
\left({ }^{\circ} \mathrm{C}\right)\end{array}$ \\
\hline & TAHQ & $N^{a)}$ & 3.3 & 0.199 & 3.26 & 0.75 & 7.07 & 10.6 & 0.224 & 471 & 452 \\
\hline \multirow[t]{3}{*}{ APAB } & M-TAHQ & 379 & 4.3 & 0.192 & 3.19 & 0.80 & 7.24 & 3.1 & 0.137 & 457 & 451 \\
\hline & MeO-TAHQ & 324 & 10.9 & 0.105 & 3.00 & 0.49 & 5.82 & 5.2 & 0.150 & 447 & 433 \\
\hline & TAHQ & 380 & 6.8 & 0.181 & 3.17 & 0.60 & 7.03 & 10.0 & 0.256 & 472 & 449 \\
\hline \multirow[t]{2}{*}{ ATAB } & M-TAHQ & 400 & 4.8 & 0.176 & 3.15 & 0.70 & 4.80 & 9.7 & 0.179 & 453 & 416 \\
\hline & MeO-TAHQ & 373 & 13.7 & 0.138 & 3.08 & 0.57 & 5.74 & 4.6 & 0.130 & 446 & 427 \\
\hline
\end{tabular}

a) ND: not detected up to $450^{\circ} \mathrm{C}$ in dynamic mechanical thermal analysis (DMTA).

Table VIII. Film properties of PEsl copolymer systems (cured at $250^{\circ} \mathrm{C} / 1 \mathrm{~h}+300^{\circ} \mathrm{C} / 1 \mathrm{~h}$ on substrate, then annealed at $350^{\circ} \mathrm{C} / 1 \mathrm{~h}$ off substrate in vacuum)

\begin{tabular}{|c|c|c|c|c|c|c|c|c|c|c|c|c|}
\hline $\begin{array}{l}\text { Tetracarboxylic } \\
\text { Dianhydride }\end{array}$ & Diamine & $\begin{array}{c}{[\eta]} \\
(\mathrm{dL} / \mathrm{g})\end{array}$ & $\begin{array}{c}T_{\mathrm{g}} \\
\left({ }^{\circ} \mathrm{C}\right)\end{array}$ & $\begin{array}{c}\text { CTE } \\
(\mathrm{ppm} / \mathrm{K})\end{array}$ & $\Delta \mathrm{n}$ & $\varepsilon_{\text {cal }}$ & $\begin{array}{l}W_{A} \\
(\%)\end{array}$ & $\begin{array}{l}\text { Modulus } \\
\text { (GPa) }\end{array}$ & $\begin{array}{l}E_{b} \\
(\%)\end{array}$ & $\begin{array}{l}\text { Strength } \\
\text { (GPa) }\end{array}$ & $\begin{array}{c}T_{\mathrm{d}}^{5} \\
\text { in } \mathrm{N}_{2} \\
\left({ }^{\circ} \mathrm{C}\right)\end{array}$ & $\begin{array}{c}T_{\mathrm{d}}{ }^{5} \\
\text { in air } \\
\left({ }^{\circ} \mathrm{C}\right)\end{array}$ \\
\hline \multirow{3}{*}{ PMDA } & $\begin{array}{c}\text { APAB60 } \\
4,4^{\prime}-\text { ODA40 }\end{array}$ & 2.36 & 382 & 11.9 & 0.148 & 3.24 & 2.5 & 3.91 & 25.5 & 0.192 & 561 & 553 \\
\hline & $\begin{array}{c}\text { APAB55 } \\
4,4^{\prime}-\text { ODA45 }\end{array}$ & 1.57 & 370 & 14.4 & 0.142 & 3.24 & 1.5 & 3.73 & 34.8 & 0.184 & 553 & 550 \\
\hline & $\begin{array}{c}\text { ATAB60 } \\
4,4^{\prime}-\text { ODA40 }\end{array}$ & 1.85 & 364 & 19.9 & 0.118 & 3.19 & 2.3 & 4.42 & 39.5 & 0.232 & 519 & 489 \\
\hline \multirow{3}{*}{ TAHQ } & $\begin{array}{c}\text { APAB70 } \\
4,4^{\prime}-\text { ODA30 }\end{array}$ & 1.08 & 395 & 14.8 & 0.170 & 3.20 & 0.66 & 6.28 & 35.8 & 0.295 & 487 & 485 \\
\hline & $\begin{array}{c}\text { APAB60 } \\
4,4^{\prime}-\text { ODA40 }\end{array}$ & 1.49 & 380 & 19.4 & 0.162 & 3.20 & 0.70 & 5.82 & 37.3 & 0.260 & 475 & 466 \\
\hline & $\begin{array}{c}\text { ATAB70 } \\
4,4^{\prime}-\text { ODA30 }\end{array}$ & 1.77 & 384 & 17.1 & 0.155 & 3.20 & 0.76 & 5.21 & 46.0 & 0.267 & 484 & 461 \\
\hline M-TAHQ & $\begin{array}{c}\text { ATAB70 } \\
4,4^{\prime}-\text { ODA30 }\end{array}$ & 3.42 & 363 & 17.8 & 0.163 & 3.16 & 0.47 & 5.36 & 41.0 & 0.193 & 461 & 451 \\
\hline
\end{tabular}

$3.3 \mathrm{ppm} / \mathrm{K}$ close to that of a silicon wafer, a low water absorption of $0.75 \%$, and high tensile modulus $(7.07 \mathrm{GPa})$ and strength $(0.224 \mathrm{GPa})$. One notices clear trends: on changing from TAHQ/APAB, M-TAHQ/APAB, and MeO-TAHQ/ APAB systems, the optically estimated dielectric constant decreased from $3.26,3.19$, and to 3.00 probably owing to both the decreases in the repeating unit polarizability and molecular packing, on the other hand, CTE increased from 3.3, 4.3, and to 10.9, reflecting the decreased birefringence as a qualitative indicator of the extent of in-plane orientation. It should be noted that the combination of MeO-TAHQ and APAB led to a very low water absorption of $0.49 \%$, thus representing a pronounced effect of the methoxy substituent on water absorption. Thermal stability decreased like TAHQ/APAB > M-TAHQ/APAB > MeO-TAHQ/APAB, although it is still sufficiently high. Similar trends for the substituent effect on CTE, $\varepsilon_{\text {cal }}, \mathrm{W}_{\mathrm{A}}$, and $T_{\mathrm{d}}{ }^{5}$ were also observed in the corresponding ATAB systems. A contradiction was seen in a comparison of the water absorption data between the MeO-TAHQ/APAB and MeO-TAHQ/ATAB systems; The latter possessing a slightly lower imide content $(20.16 \mathrm{wt} \%)$ showed a higher water absorption $\left(\mathrm{W}_{\mathrm{A}}=0.57 \%\right)$ than the corresponding $\mathrm{APAB}$ system (imide content $=20.58 \mathrm{wt} \%, \mathrm{~W}_{\mathrm{A}}=0.49 \%$ ) in contrast to our first expectation that the imide content must be a crucial factor influencing the water absorption of PI films. A possible explanation is that other secondary factors such as the fraction and size of free volume and moisture permeation properties also influence somewhat water absorption. For these homo PEsI systems, the substituents were not effective to improve film toughness $\left(\mathrm{E}_{\mathrm{b}}\right)$.

\section{PEsI Copolymer Systems}

The results described above revealed that most of rigid homo PEsI systems displayed too low CTE values for FCCL application. However, this is a big advantage rather than a drawback because one can use an established content of adequate flexible monomers to completely erase the internal stress in the PEsI/copper laminates by precisely controlling the CTE values through copolymerization. This approach is also expected to improve significantly the film toughness simultaneously. To determine the PEsI copolymer composition (flexible diamine content) suitable for complete CTE matching with that of copper foil is beyond the present purpose. Therefore, we evaluated the film properties of PEsI copolymer systems with a typical composition (60 or $70 \mathrm{~mol} \%$ of rigid diamine components). In this case, $4,4^{\prime}$-ODA was chosen as a flexible comonomer from the view points of its high reactivity and cost performance. Table VIII summarizes the film proper- 
ties of the PEsI copolymer systems examined. The incorporation of $40 \mathrm{~mol} \% 4,4^{\prime}-\mathrm{ODA}$ into the rigid $\mathrm{PMDA} / \mathrm{APAB}$ system significantly improved the film toughness (from $\mathrm{E}_{\mathrm{b}}=6.4 \%$ for PMDA/APAB to $\mathrm{E}_{\mathrm{b}}=25.5 \%$ for PMDA/ (APAB60; 4,4'-ODA40) copolymer) without sacrificing high $T_{\mathrm{g}}$ and low CTE characteristics although the CTE value $(11.9 \mathrm{ppm} / \mathrm{K})$ is still too low compared to that of copper foil $(17-18 \mathrm{ppm} / \mathrm{K})$ as the present target. At a 4,4'-ODA content of $55 \mathrm{~mol} \%$, the film toughness was furthermore improved with a still slightly lower CTE value $(14.4 \mathrm{ppm} / \mathrm{K})$ than the target value, although the incorporation of $50 \mathrm{~mol} \% 4,4^{\prime}$-ODA caused an increased CTE $(25.2 \mathrm{ppm} / \mathrm{K}$ ) (not listed in the table). A positive substituent effect was observed in a comparison between the copolymer systems, non-substituted APAB60; 4,4'-ODA40 and methyl-substituted ATAB60; 4,4'ODA, that is, an improved toughness from $\mathrm{E}_{\mathrm{b}}=25.5 \%$ for the former to $E_{b}=39.5 \%$ for the latter. This can not be simply interpreted from the difference of molecular weights since the latter has a lower $[\eta]$ value. A possible explanation for this substituent effect is an increased degree of polymer chain entanglement, although the actual film toughening mechanism is probably very complex and involves many factors such as not only molecular weight (chain length) but also chain conformations, local motions, and morphology (crystallinity, local ordering).

The results also revealed that there seems to be a limit to decrease drastically the water absorption as far as PMDA is used as a tetracarboxylic dianhydride component owing to the resultant higher imide contents. This problem could be solved by choosing TAHQ or M-TAHQ instead of PMDA. As shown in Table VIII, the TAHQ/(APAB; 4,4'-ODA) copolymer systems achieved good balanced properties such as a very high $T_{\mathrm{g}}$ approximate to $400{ }^{\circ} \mathrm{C}$, a low CTE approximate to the target value, low water absorption, and good toughness. It should be noted that the corresponding ATAB-based PEsI copolymer improved furthermore the film toughness $\left(E_{b}=46.0 \%\right)$ as observed in the PMDA-based copolymers.

The results also reveled that the M-TAHQ/(ATAB70; 4,4'ODA) copolymer system finally accomplished the lowest water absorption $(0.47 \%)$ among the non-fluorinated PEsI systems examined in this work together with a completely consistent CTE with that of copper foil and good flexibility. Thus, the combined effect of adequate substituents and flexible comonomer provided us a new type of FCCL base film material.

\section{CONCLUSION}

The incorporation of methyl and methoxy substituents into rigid TAHQ-based PEsI systems did not contribute basically to the decreases in $T_{\mathrm{g}}$ but allowed molecular motions above the $T_{\mathrm{g}}$ s. Particularly in the TFMB-based PEsI systems, the use of M-TAHQ and MeO-TAHQ caused significantly allowed $\beta$ transitions around $200-240{ }^{\circ} \mathrm{C}$. In some cases, a substituent effect was also observed on water absorption in the homo PEsI systems containing whether the TAHQ series or the APAB series or both: the water absorption tended to decrease by incorporation of these substituents. In particular, the methoxy group was effective.

$4,4^{\prime}$-ODA was copolymerized to incorporate flexible linkages into the rigid backbones of highly esterified PEsIs. The PEsI copolymers obtained achieved a low CTE approximate to that of copper foil, low water absorption, a high $T_{\mathrm{g}}$, and significantly improved toughness at the same time. In this case, the use of ATAB instead of APAB contributed to further improvement of film toughness. We finally obtained a PEsI copolymer, M-TAHQ/(ATAB70; 4,4'-ODA30), as a novel base film material for FPC application, which accomplished the lowest level of water absorption $\left(\mathrm{W}_{\mathrm{A}}=0.47 \%\right)$ among our fluorine-free PEsI systems examined so far, a completely copper-consistent CTE $(17.8 \mathrm{ppm} / \mathrm{K})$, a high $T_{\mathrm{g}}$ exceeding $360{ }^{\circ} \mathrm{C}$ in addition to good toughness $\left(\mathrm{E}_{\mathrm{b}}>40 \%\right)$.

Acknowledgment. We thank Dr. A. Tamaki at Wakayama Seika Kogyo for supplying APAB and ATAB.

Received: September 20, 2007

Accepted: October 20, 2007

Published: November 27, 2007

\section{REFERENCES}

1. "Polyimides: Synthesis, Characterization and Application," K. L. Mittal, Ed., Plenum, New York, 1984.

2. "Polyimide: Thermally Stable Polymers," M. I. Bessonov, M. M. Koton, V. V. Kudryavtsev, and L. A. Laius, Ed., Plenum, New York, 1987.

3. "Polyimides: Materials, Chemistry and Characterization," C. Feger, M. M. Khojasteh, and J. E. McGrath, Ed., Elsevier, Amsterdam, 1989.

4. "Advances in Polyimide Science and Technology," C. Feger, M. M. Khojasteh, and M. S. Htoo, Ed., Technomic, Lancaster, 1993.

5. "Polyamic acid and Polyimides: Synthesis, Transformation and Structure," M. I. Bessonov and V. A. Zubkov, Ed., CRC Press, Boca Ranton, FL, 1993.

6. "Polyimides: Fundamentals and Applications," M. K. Ghosh and K. L. Mittal, Ed., Marcel Dekker, New York, 1996.

7. "Polyimides: Trends in Materials and Applications," C. Feger, M. M. Khojasteh, and S. E. Molis, Ed., Society of Plastic Engineers, New York, 1996.

8. "Advances in Polyimides and Low Dielectric Polymers," H. S. Sachdev, M. M. Khojasteh, and C. Feger, Ed., Society of Plastic Engineers, New York, 1999.

9. "Polyimides and Other High Temperature Polymers: Synthesis, Characterization and Applications," vol. 1, K. L. Mittal, Ed., VSP, Zeist, The Netherland, 2001.

10. "The Latest Polyimides: Fundamentals and Applications," Y. Imai and R. Yokota, Ed., NTS, Tokyo, 2002.

11. S. Numata, S. Oohara, K. Fujisaki, K. Imaizumi, and N. Kinjyo, $J$. Appl. Polym. Sci., 31, 101 (1986).

12. S. Numata, K. Fujisaki, and N. Kinjyo, Polymer, 28, 2282 (1987).

13. M. Hasegawa, T. Matano, Y. Shindo, and T. Sugimura, Macromolecules, 29, 7897 (1996).

14. J. C. Coburn and M. T. Pottiger, in "Polyimides: Fundamentals and Applications," M. K. Ghosh and K. L. Mittal, Ed., Marcel Dekker, New York, 1996, p 207.

15. T. Kikuchi and T. Saito, Kagaku (Chemistry), 43, 668 (1988).

16. A. Morikawa and K. Ono, High Perform. Polym., 13, S73 (2001).

17. M. Hasegawa and M. Koyanaka, High Perform. Polym., 15, 47 
(2003).

18. M. Hasegawa and S. Horii, Polym. J., 39, 610 (2007).

19. M. Hasegawa and K. Koseki, High Perform. Polym., 18, 697 (2006).

20. D. F. Loncrini, J. Polym. Sci.: Part A-1, 4, 1531 (1966).

21. M. Bruma, I. Sava, F. Mercer, I. Negulescu, W. Daly, J. Fitch, and P. Cassidy, High Perform. Polym., 7, 411 (1995).

22. Y. Tong, D. Dong, and M. Ding, J. Polym. Mater., 18, 449 (2001).

23. S. Mehdipour-Ataei and S. Keshavarz, J. Appl. Polym. Sci., 89, 2567 (2003).

24. D. J. Liaw, C. L. Fan, C. C. Lin, and K. L. Wang, J. Appl. Polym. Sci., 92, 2486 (2004).

25. H. Behniafar, B. Akhlaghinia, and S. Habibian, Eur. Polym. J., 41, 1071 (2005).

26. S. H. Hsiao and W. T. Leu, High Perform. Polym., 16, 461 (2004).

27. T. Jinta and T. Matsuda, Kobunshi Ronbunshu, 45, 215 (1988).

28. D. Dong, H. Zhuang, G. Li, Y. Ni, and M. Ding, J. Polym. Sci., Part A: Polym. Chem., 37, 211 (1999).

29. C. Wutz, Polymer, 41, 4957 (2000).
30. H. R. Kricheldorf, M. Rabenstein, and G. Schwarz, Polymer, 42, 1789 (2001).

31. M. Hasegawa, M. Horiuchi, and Y. Wada, High Perform. Polym., 19, 175 (2007).

32. M. Hasegawa, N. Sensui, Y. Shindo, and R. Yokota, Proceedings of 5th European Technical Symposium of Polyimides and High Performance Functional Polymers (STEPI5), 1999, p 194.

33. M. Hasegawa, N. Sensui, Y. Shindo, and R. Yokota, Macromolecules, 32, 387 (1999).

34. M. Hasegawa, N. Sensui, Y. Shindo, and R. Yokota, J. Polym. Sci., Part B: Polym. Phys., 37, 2499 (1999).

35. Z. Shi, M. Hasegawa, Y. Shindo, R. Yokata, F. He, H. Yamaguchi, and H. Ozawa, High Perform. Polym., 12, 377 (2000).

36. M. Hasegawa, M. Chihara, K. Koseki, and A. Tominaga, Polym. Prepr. Jpn., 55, 1598 (2006).

37. M. Hasegawa and K. Horie, Prog. Polym. Sci., 26, 259 (2001).

38. M. Hasegawa, Y. Tanaka, K. Koseki, and A. Tominaga, J. Photopolym. Sci. Technol., 19, 285 (2006). 